\title{
Food and Trophic Relationships of Four Mullet Fish (Mugilidae) in the Shatt Al-Arab River, Iraq
}

\author{
Abdul-Razak M. Mohamed ${ }^{1 *}$ and Abdullah N. Abood² \\ ${ }^{1}$ Department of Fisheries and Marine Resources, College of Agriculture \\ University of Basrah, Iraq \\ ${ }^{2}$ Basrah Agriculture Directorate, Ministry of Agriculture \\ Iraq \\ *Corresponding author's email: abdul19532001 [AT] yahoo.com
}

\begin{abstract}
Food composition and feeding relationships of four mullet species, Planliza abu, P. subviridis, $P$. klunzingeri and Osteomugil speigleri from the Shatt Al-Arab River, Iraq, were assessed during 2016-2017.Fish were captured by gill nets, cast net and electro-fishing. The index of relative importance (IRI\%) of food item was determined by combined the frequency of occurrence and points methods. Monthly variations in feeding activity and intensity of all species were observed. All species were herbivorous and P. abu and P. klunzingeri were considered non-specialized feeders, while P. subviridis and $O$. speigleri were low specialist feeders. $P$. abu fed mainly on diatoms (38.6\%), high plants (21.7\%), algae (15.9\%), detritus (15.3\%), fish eggs (6.9\%) and zooplankton (1.6\%).The diet of P. subviridis constituted from diatoms (42.2\%), high plants (20.9\%), detritus (17.7\%), algae (15.9\%), zooplankton (2.0\%) and fish eggs (1.8\%). P. klunzingeri fed mainly on diatoms (35.5\%), high plants (29.3\%), detritus (16.4\%), algae (13.4\%), fish eggs (4.1\%) and zooplankton (2.4\%). O. speigleri were consumed mainly diatoms (52.0\%), detritus (17.8\%), algae (16.6\%), high plants (10.7\%), zooplankton (2.5\%) and fish eggs (2.4\%). Similarity dendrogram among fish species based on their diet showed high significant overlaps among the mullet species. It means that these species might be in direct competition for food in the Shatt Al-Arab River.
\end{abstract}

Keywords-- Mullet fish, food habit, herbivorous, Shatt Al-Arab River, Iraq

\section{INTRODUCTION}

Mugilidae is a widely distributed family and its member species are generally known as mullets inhabit coastal waters and estuaries of the tropical and subtropical zones of world seas, but also depending on the species, spend part or even their whole life cycle in coastal lagoons, lakes and rivers [1].This family represented of 303 available species and only 77 valid species [2]. Mullets constituted a very significant contribution (30\%) to the production of pelagic fish in the northwest Arabian Gulf [3]. Five species of mullets inhabit the Iraq waters, four in marine waters (Planliza subviridis, $P$. carinata, P. klunzingeri and Osteomugil speigleri), locally known as Beyah and one species, $P$. abu locally known as Khishni lives in fresh and brackish waters [4-5]. The contribution of mullet's species in the Iraqi marine waters increased from $12.3 \%$ (2239.6 tons) during 1990-1994 [6] to 22.1\% (6651.0 tons) from the total landings during 2008-2018 [7].

Information on the food habits and trophic interrelationships of fish is essential to understand the life history of fish including growth, behavior, reproduction, migration and other vital activities of fish, and also help to understand the predicted changes on ecosystem due to natural or anthropogenic interventions [8-9].

Many researchers have published their reports on food habits of mullet fish at different water bodies of Iraq; about $P$. $a b u$ [10-21] and about Planliza subviridis and P. klunzingeri [14, 22-24, 21, 25], but up until now, the food habit of $O$. speigleri in the waters of Iraq have not been studied.

Studies on the trophic relationships between some mullet species and other fish species have been made by many workers at different Iraqi waters [26-28, 21, 29-32].

During the last years, the Shatt Al-Arab River has been suffered from the deterioration of the water quality due to series of anthropogenic activities such as agricultural runoff wastes and untreated wastewater, invasion of fish species and seawater intrusion as a result of drastically reduced in water quantity and quality related to the decline in rates of the flow from the Tigris, Euphrates and Karun Rivers [33-35]. Therefore, the present work is designed to described the food and trophic relationships of $P . a b u, P$. subviridis, $P$. klunzingeri and $O$. speigleri in the Shatt Al-Arab River under this circumstance. 


\section{MATERIALS AND METHOD}

The Shatt Al-Arab River forms from the confluence of the Tigris and Euphrates rivers at Al-Qurna town, in the southern of Iraq, and flows to southeastern direction towards the Arabian Gulf (Fig. 1). It is about $204 \mathrm{~km}$, and varies in width from 250to $1,500 \mathrm{~m}$ at the estuary. The river is affected by the tidal current of the Gulf. Fish were sampled monthly between November 2015 and October 2016 from the three sites on the river. Site 1 (upstream) is located near Al-Dair Bridge, site 2 (midstream) is sited in Abu Al-Khasib district and site 3 (downstream) is located north Al-Fao town (Fig. 1).

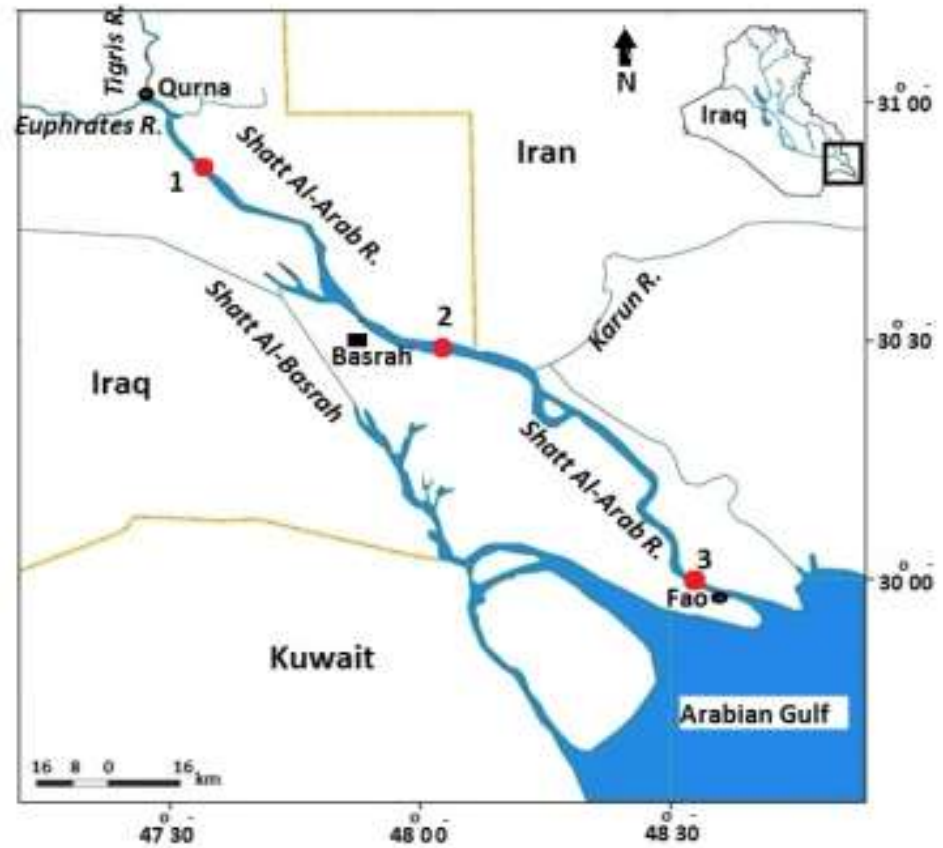

Figure 1: Map of Shatt Al-Arab River with locations of study sites.

The fish were caught from each site using various devices including gill nets, cast net and electro-fishing. After capture, the fish were preserved in ice in a cooler box prior to dissection in the laboratory. Some relevant ecological factors were determined in situ namely, water temperatures and salinity.

During laboratory analysis, the total length (TL, cm) of each fish was measured. The gut of the fish was removed by making a longitudinal incision along the mid ventral line. The stomach was cut off from the gut and gives the degree of fullness, and then opened in Petri dish to examine different food items. The stomachs were scored 0, 5, 10, 15 and 20 points according to its fullness as described by [36] Hynes (1950). Each stomach was split open and the contents emptied into a Petri-dish. The contents were then observed under a stereoscopic microscope. The food items were identified with the aid of keys provided by [37], [38] and [39].The food items were grouped into diatoms, high plants, algae, detritus, fish eggs and zooplankton.

The stomach content was analyzed on the basis of the percentage of points $(\mathrm{P} \%)$ and frequency of occurrence $(\mathrm{O} \%)$ methods following [40]. The importance of food item was determined by combined the two methods to calculate the index of relative importance (IRI\%) of [41] as follows:

$$
\mathrm{IRI}=\mathrm{O} \% \times \mathrm{P} \% \text { and IRI } \%=\mathrm{IRI} / \Sigma \mathrm{IRI} * 100
$$

Feeding intensity and feeding activity for each monthly sample were calculated after [42] and [43], respectively. The feeding index was determined after [45]. The vacuity index was calculated as the number of empty stomachs divided by the number of stomachs analyzed [46].

The trophic niche breadth for each species was calculated according to the formula proposed by [47]:

$$
\mathrm{B}=1 / \Sigma \mathrm{P}_{\mathrm{i}} \wedge^{2}
$$

where, $\mathrm{B}$ is Levins index of niche breadth and $\mathrm{P}_{\mathrm{i}}$ is proportion of food group (i) in the diet. To standardize niche breadth on a scale from 0 to 1 , the modification suggested by [48] was adopted as follows:

$$
\mathrm{B}_{\mathrm{A}}=(\mathrm{B}-1) /(\mathrm{n}-1)
$$

where, $\mathrm{B}_{\mathrm{A}}$ is Levins standardized niche breadth, $\mathrm{B}$ is Levins index of niche breadth and $\mathrm{n}$ is number of food groups for each species. This index was used to test the feeding specialization of each species. The highly specialized feeder's species 
fall within the range of 0.0-0.25, while the low specialized feeders between 0.26-0.49 and non-specialized (generalized) feeders are within the range of 0.50-1.0.

The dietary overlap among diets of mullet species was evaluated using cluster analyses for food items that represented more than $10 \%$ relative importance were considered major items in the diet of each species and according to the method described by [49].

\section{RESULTS}

Food habits of 1,762mullet's fish were assessed, including 555 of $P$. abu (TL=65-195 mm), 456 of $P$. subviridis (TL= 98-265 mm), 564 of $P$. klunzingeri $(\mathrm{TL}=96-227 \mathrm{~mm})$ and 187 of O. speigleri $(\mathrm{TL}=115-181 \mathrm{~mm})$.

The monthly changes in the feeding activity and intensity of the four species are given in Figure 2 . The feeding activity of $P$. a $a$ u fluctuated from $56.1 \%$ in January to $98.2 \%$ in July, and the feeding intensity ranged from 5.2 point/fish in July to 11.2 point/fish in September. The feeding activity of $P$. subviridis varied from $39.1 \%$ in January to $97.6 \%$ in September, whereas, the feeding intensity fluctuated from 5.0 point/fish in July to 12.7 point/fish in September. The feeding activity of $P$. Klunzingeri changed from $45 \%$ in January to $100 \%$ in April, while, the feeding intensity ranged from 7.0 point/fish in December to 10.2 point/fish in April. O. speigleri individuals were not caught during November, February and May. The feeding activity of this species changed from 55\% in January to $100 \%$ in April, and the feeding intensity varied from 5.5 point/fish in January to 10.8 point/fish in April.

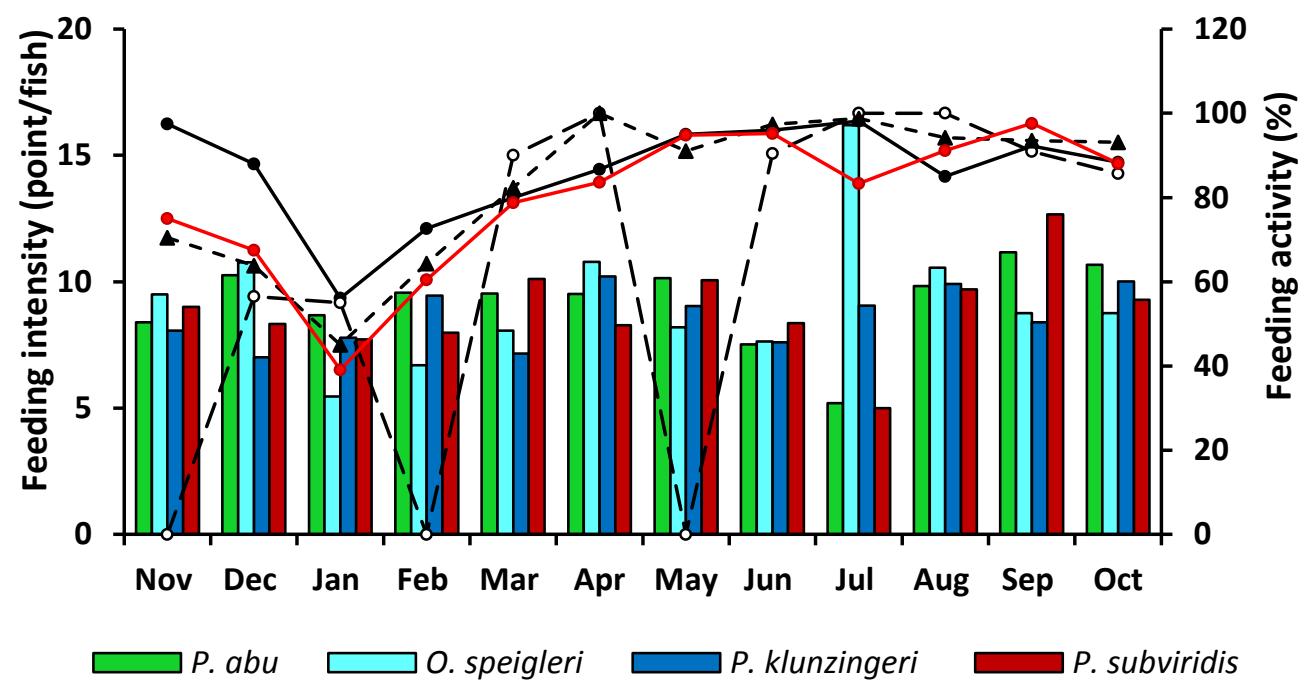

Figure 2: Monthly changes in feeding activity and intensity of four species

The monthly fluctuations in the feeding and vacuity indices of $P$. abu, P. subviridis, P. Klunzinger and O. speigleri in the Shatt Al-Arab River are illustrated in Figure (3).The feeding index of $P$. abu ranged from $26.0 \%$ in July to $55.8 \%$ in September, $P$. subviridis varied from $25.0 \%$ in July to $63.3 \%$ in September, $P$. klunzingeri fluctuated from $30.8 \%$ in December to $50.9 \%$ in April and $O$. speigleri differenced from $27.3 \%$ in January to $81.0 \%$ in July. The overall values were $45.8,44.4,43.2$ and $36.2 \%$ for the four species, respectively. The vacuity index of $P$. abu fluctuated from $1.9 \%$ in July to $43.9 \%$ in January, $P$. subviridis varied from $2.4 \%$ in September to $60.9 \%$ in January, P. klunzingeri varied from $0.0 \%$ in April to $55.0 \%$ in January and O. speigleri changed from $0.0 \%$ in November, February, April, May, July and August to $45.0 \%$ in January. The overall values of vacuity index for the four species were 13.7, 20.7, 17.2and 11.0\%, respectively. 


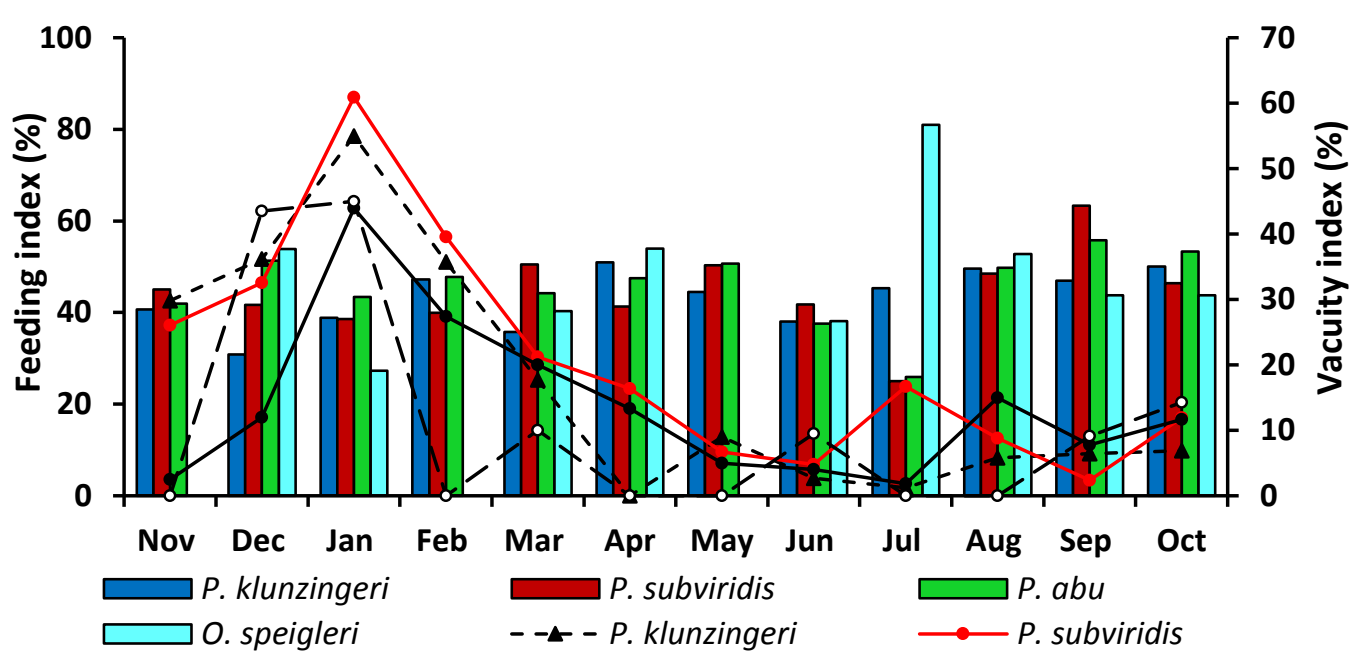

Figure 3: Monthly variations in the feeding and vacuity indices of the four species

The monthly data of various food items of $P$. abu, P. subviridis, P. klunzingeri and $O$. speigleri were pooled to describe the seasonal variations in the food habits of the species (Fig. 4). It appeared that all species depend on four major food items. Diatoms were the dominant item in the gut of $P . a b u$ during the study period and the percentage contribution according to the index of relative importance (IRI) ranged from $25.0 \%$ in summer to $55.1 \%$ in winter. The second most important food item was high plants constituting $7.5 \%$ in winter and $20.9 \%$ in summer. Algae occupied the third position and ranged from $9.8 \%$ in winter to $21.6 \%$ in autumn. The contribution of detritus in the diet of the species fluctuated from $11.7 \%$ in summer to $19.2 \%$ in autumn. The additional food composed of fish eggs and zooplankton were mainly consumed in autumn and spring, respectively. Generally, this species is classified as herbivorous and fed mainly on diatoms (38.6\%), high plants $(21.7 \%)$, algae (15.9\%), detritus (15.3\%), fish eggs (6.9\%) and zooplankton (1.6\%).

P. subviridis consumed mostly diatoms and their percentage varied from $34.5 \%$ in summer to $48.4 \%$ in spring. High plants occupied the second position and ranged from $14.4 \%$ in spring to $30.3 \%$ in summer. Detritus came in the third place and fluctuated from $12.3 \%$ in spring to $22.8 \%$ in summer. The lowest value of algae in the diet of $P$. subviridis was $10.4 \%$ in summer and the highest value was $22.2 \%$ in spring. The other food items were zooplankton and fish eggs fluctuated over season, but their highest values were observed in winter. However, the overall food items of $P$. subviridis were constituted from diatoms (42.2\%), high plants (20.9\%), detritus (17.7\%), algae (15.9\%), zooplankton (2.0\%) and fish eggs (1.8\%).

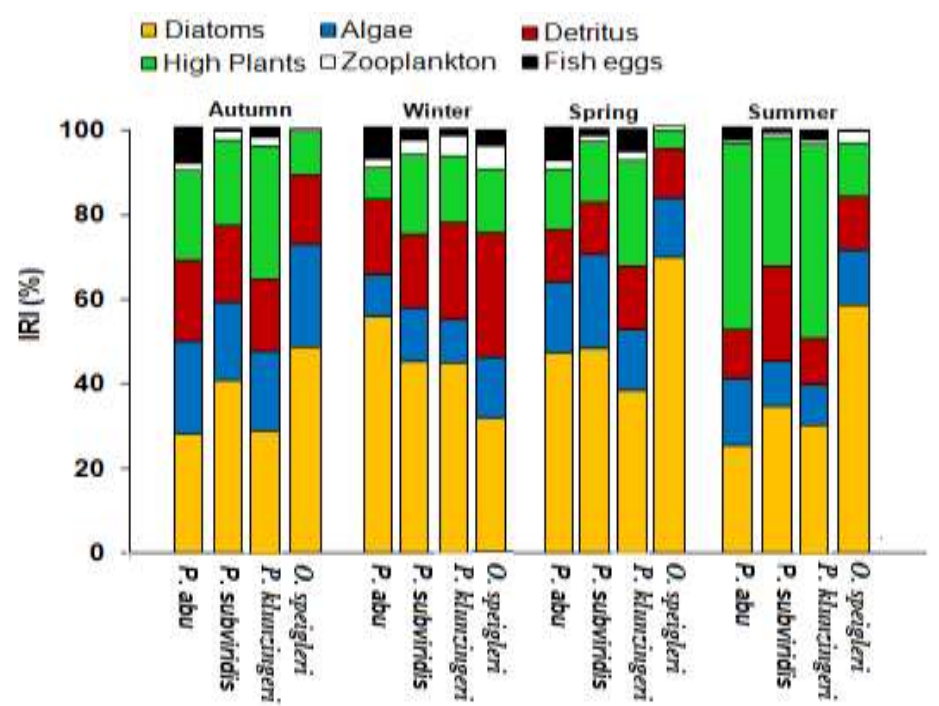

Figure 4: Seasonal changes in the IRI\% of food items in the diet of the three species 
The major food item of $P$. klunzingeri was diatoms, their percentage contribution ranged from $28.9 \%$ during autumn and $44.6 \%$ during winter, while the contribution of high plants varied from $15.5 \%$ in winter to $45.4 \%$ in summer. Detritus occupied the third position and fluctuated from $10.9 \%$ in summer to $23.1 \%$ in winter. The lowest value of algae in the diet of $P$. Klunzingeri was $9.7 \%$ in summer and the highest value was $18.7 \%$ in autumn. The highest values of fish eggs and zooplankton in the diet of the specieswere $5.6 \%$ and $4.8 \%$ in spring and winter, respectively. Generally, this species fed mainly on diatoms (35.5\%), high plants (29.3\%), detritus (16.4\%), algae (13.4\%), fish eggs (4.1\%) and zooplankton (2.4\%).

The diet of $O$. speigleri was mainly dominated by diatoms, which ranged between $32.2 \%$ in winter and $68.9 \%$ in spring. Detritus occupied the second position and ranged from $11.6 \%$ in spring to $30.3 \%$ in winter. Algae came third and varied from $12.9 \%$ in summer to $24.5 \%$ in autumn. The contribution of high plants fluctuated from $4.4 \%$ in spring to $15.4 \%$ in winter. The highest values of zooplankton and fish eggs in the diet of the specieswere $5.3 \%$ and $4.2 \%$ in winter, respectively. The overall food items of $O$. speigleri were formed from diatoms $(52.0 \%)$, detritus (17.8\%), algae (16.6\%), high plants $(10.7 \%)$, zooplankton $(2.5 \%)$ and fish eggs $(2.4 \%)$.

The feeding selectivity index for the various diet items of P. abu, P. subviridis, P. klunzingeri and $O$. speigleri in the Shatt Al-Arab is illustrated in Figure6. The highest mean value of the index $(38.5 \%)$ was for diatoms with the maximum value $(29.9 \%)$ for $P$. $a b u$, followed by high plants(23.3\%) with the highest value $(43.4 \%)$ for P. klunzingeri. Algae ranked third with $14.2 \%$ and the maximum value(34.4\%) for $P$. $a b u$. Detritus came fourth with $14.1 \%$ and the highest value (33.4\%)for $P$. $a b u$. Fish eggs ranked fifth by $3.3 \%$ and the maximum value $(69.0 \%)$ for $P$. abu. Zooplankton placed sixth with $1.6 \%$ and the highest value $(34.2 \%)$ for $P$.

The results of feeding specialization for the four species showed that the index of Levins standardized niche breadth for $P$. subviridis and $O$. speigleri were low specialist feeders $\left(B_{i}=0.492\right.$ and 0.365 , respectively), while $P$. $a b u$ and $P$. klunzingeri were considerednon-specializedfeeders $\left(B_{i}=0.575\right.$ and 0.551 , respectively).

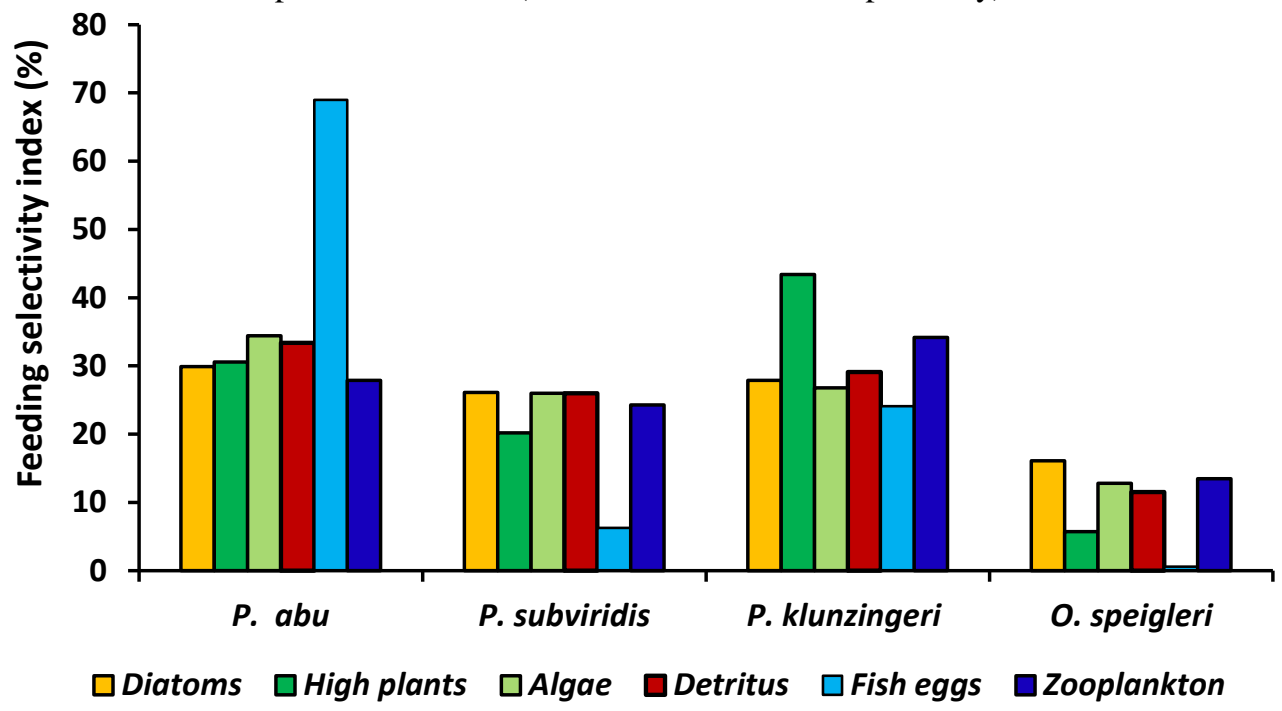

Figure 5: Feeding selectivity index for the different food items of the four species

Similarity dendrogram among fish species based on their diet showed high significant overlaps $(\mathrm{C} \lambda=1.000)$ among the mullet species, the overall feeding patterns of the four species characterized by high intake of food items of diatoms, high plants and algae.

\section{DISCUSSION}

The study revealed that all studied species are continuous feeders and never cease feeding all the year round, despite notable monthly fluctuations in their feeding activities and intensities. The higher values of feeding intensity and activity which recorded in warm periods of the year were coincided with rise in ambient water temperature. [50] stated that the water temperature is the principal environmental factor affecting the gut fullness of fish. This finding agreed with the previous dietary studies on these species, such as [27] on P. subviridis in Garmat Ali River; [20] on P. abu in Tigris River and [51] on $P$. $a b u$ in Eastern Drainage River, Tikrit, Iraq. 
The results exhibited that the $P . a b u$ in the present study was herbivorous, non-specialized feeder and fed mainly on plant components (diatoms, 38.6\%, high plants, $21.7 \%$ and algae, 15.9\%). The dominant of diatoms in the diet of the species is in agreement with the findings of several studies. [27] Lasim (2009) found that diatoms formed 58.6\% of $P$. abu diet in Garmat Ali River. [52] stated that P. abu consumed diatoms (79.4\%) and algae (119.0\%) in southern marshes, Iraq. [31] Mohamed et al. (2015) stated that diatoms (42.1\%3), algae (26.6\%) and detritus (15.6\%) were apparent in the gut of P. abu in East Hammar marsh. However, [14] mentioned that P. abu consumed detritus (19.9\%), high plants (17.2\%), algae $(17.2 \%)$ and diatoms $16.0 \%)$ in Shatt Al-Basrah. [20] found detritus (31.6\%), algae (18.2\%), zooplankton (12.3\%), aquatic plants $(8.9 \%)$ and diatoms $(5.7 \%)$ in the gut of $P . a b u$ in Tigris River.

During the present work, P. klunzingeri was found to be herbivores, non-specialized feeder and consumed mainly diatoms $(35.5 \%)$, high plants $(29.3 \%)$,detritus $(16.4 \%)$ and algae $(15.9 \%)$. Some previous studies have the same results, such as [27] mentioned that P. klunzingeri in Karmat Ali River fed on diatoms (42.0\%), alge (21.7\%), detritus (15.1\%) and high plants (8.4\%) and [24] stated that the species consumed diatoms (37.0\%), detritus (34.0\%), high plants $(9.0 \%)$ and alge $(9.0 \%)$.Whereas, other studies reported that detritus constituted the bulk of the food of the species [52, 32].

P. subviridis was found to be herbivorous, low specialist feeder and fed more on diatoms (35.5\%), high plants (29.3\%), detritus $(16.4 \%)$ and algae $(13.4 \%)$ in the present study. Several authors considered the diatoms were the most important food items for this species [52, 27, 24, 21]. However, [14] stated that this species consumed algae (30.1\%), high plants (16.4\%), diatoms (15.0\%) and detritus (13.9\%) in Shatt Al-Basrah canal. [22] found detritus (35.1\%), diatoms (20.0\%), crustacean $(6.3 \%)$ and high plants $(6.2 \%)$ were the food items for $P$. subviridis in Khor Al-Zubair. [23] mentioned that $P$. subviridis fed mainly on detritus $(19.1 \%)$, diatoms $(16.7 \%)$, high plants $(12.7 \%)$ and algae (12.5\%) in the Iraqi marine waters. [31] stated that algae (34.3\%), diatoms (33.2\%) and detritus (13.0\%) were the common food items found in the gut of $P$. subviridis in East Hammar marsh.

The food analyses of the gut of $O$. speigleri clearly indicated that the fish was herbivores, low specialist feeder and consumed mainly diatoms $(52.0 \%)$, detritus $(17.8 \%)$, algae $(16.6 \%)$, high plants $(10.7 \%)$ in the present study. [53] mentioned that $O$. speigleri fed mainly on detritus (26.7\%), diatoms $(13.7 \%)$, high plants $(10.4 \%)$ and algae $(10.1 \%)$ in Iraqi marine waters.

Analysis of food similarity between the four species showed high significant overlaps among the mullet species, all fed mostly on plant origin than the other. It means that these species might be in direct competition for food in the Shatt Al-Arab River. [54] mentioned that mullets are herbivorous and/or detritivorous fish, feeding on algae, diatoms and small invertebrates associated with algae, and detritus obtained from bottom muds and sands.

[55] stated that the diet of most species of mullet fish in the St. Lucia lake system of South Africa consisted of snail, Assiminea bifasciata, foraminifera, the large centric diatom Aptinoptychus splendens, small centric and pennate diatoms, and filamentous algae. Moreover, [56] mentioned that the Plant materials were the most abundant food items by numerical and occurrence methods in the gut of two mullet species and diatom formed the most frequently consumed food item by both species in the estuary of Merbok, Malaysia. It is well known that the feeding and trophic relationships of fish change with availability of food, locality and spatial distribution within the habitat [57]. Also, it is a widely accepted generalization that stream fish are mostly opportunistic in their feeding habits because of the highly variable nature of habitat and resources [58].

\section{CONCLUSION}

The results revealed that the fish assemblage in the river was clearly shifted in the number of species, the percents of exotic and marine species and the dominancy species compared with the previous status.

\section{REFERENCES}

[1] González-Castro M, Ghasemzadeh, J. "Morphology and morphometry based taxonomy of Mugilidae”. In: Crosetti D, Blaber S. (eds.). Biology, ecology and culture of grey mullet (Mugilidae). CRC Press, Boca Raton, USA. Pp. 1-21. 2015.

[2] Eschmeyer WN, Fong JD. “ Species by family/subfamily”. (http://researcharchive. calacademy. org/research/ichthyology/catalog/ SpeciesByFamily.asp). Online Version, Updated 30 April 2018.

[3] Sivasubramaniam K. "Pelagic resources of the Gulf and Gulf of Oman". FAO. Publ. FI: DP/ RAB/71/278/11, Pp. 1144, 1981.

[4] Mohamed ARM, Abood AN, Hussein SA. "Comparative taxonomy study of four mullet species (Mugilidae) from Iraqi marine waters, Arabian Gulf”. Basrah J. Agric. Sci., vol 29, pp. 11-20, 2016. 
[5] Mohamed ARM, Abood AN, Hussein SA. "Taxonomy Study of Planiliza (Liza) abu in Garmat Ali River, Iraq". Scientific Journal of King Faisal University, vol 19, pp. 11-20, 2018.

[6] Ali TS, Mohamed ARM, Hussain NA. "The Status of Iraqi Marine Fisheries during 1990-1994". Marina Mesopotamica, vol. 13, pp. 129-147, 1998.

[7] Mohamed ARM. "Assessment and management of Iraqi marine artisanal fisheries, northwest of the Arabian Gulf". Journal of Agriculture and Veterinary Science. Vol. 11, pp. 85-92, 2018.

[8] Priyadharsini S, Manoharan J, Varadharajan D, Subramaniyan A. "Interpretation of the food and feeding habits of Dascillus trimaculatus (Ruppell, 1829) from Gulf of Manner, South East Coast of India”. Archives of applied Science Research, vol. 4, pp. 1758-1762, 2012.

[9] Sajeevan MK, Kurup BM. "Evaluation of feeding indices of cobia Rachycentron canadum (Linnaeus. 1766) from northwest coast of India". J. Mar. Biol. Ass. India, vol. 55, pp. 16-21, 2013.

[10] Al-Nasiri SK, Saker AL, Shamsul-Hoda SMS. "Feeding ecology of mugilid fish Liza abu (Heckel) in Basrah, Iraq". Bull Basrah Nat. Hist. Mus., vol. 4, pp. 27-40, 1977.

[11] Barak NA.” Study of food habits of three Iraqi fish species in Al-Saklawia drainage”. MSc. Thesis, College of Science, University of Baghdad. 147p, 1978.

[12] Ahmad TA, Hussian NA. "Observation on the food of young Liza abu (Heckel ) from Salihyia River, Basrah, Iraq". Journal of Marine Science, vol. 1, pp. 79-88, 1982.

[13] Naama AK. "Some biological aspects of two freshwater fish, Liza abu and Mugil dussummieri in Hammar marsh, north of Basrah, Iraq". MSc. Thesis, College of Science, University of Basrah, 161p, 1982.

[14] Wahab NK. "Ecology and biology of three species of mugilid fishes in Shatt Al-Basrah Canal". Msc. Thesis, University of Basrah, College of Agriculture, 155 pp, 1986.

[15] Wahab NK. "Food habits and food relationship for some freshwater fish species in Al-Tharthar arm-Tigris-Sammara", Iraq. Basrah J. Agric. Sci., vol. 26, pp. 182-197, 2013.

[16] Al-Asadiy YD, Mhaisen FT, Dauod HAM. "Food and feeding habits of the mugilid fish Liza abu (Heckel) in a fish farm at Babylon province, mid Iraq". IBN Al-Haitham J. for Pure \& Appl. Sci., vol. 14, pp. 1-8, 2001.

[17] Al-Shawi SAS, Wahab NK. "Some biological aspects of Liza abu (Heckel) fish in Tuz-Chi tributary, north Iraq". Samara Journal, Vol. 15, pp. 214-228, 2008.

[18] Mohamed ARM, Hussain NA, Al-Noor SS, Coad BW, Mutlak FM, Al-Sudani IM, Mojer AM, Toman AJ. "Species composition, ecological indices and trophic pyramid of fish assemblage of the restored Al-Hawizeh Marsh, Southern Iraq". Ecohydrology \& Hydrobiology, vol. 8, pp. 375-384, 2008.

[19] Mohamed ARM, Hussain NA, Al-Noor SS, Mutlak FM. "Ecological and biological aspects of fish assemblage in the Chybaish marsh, Southern Iraq". Ecohydrology \& Hydrobiology, vol. 12, pp. 65-74, 2012.

[20] Al-Shamma'a AA, Al-Azawi BM, Shawardi AA. "Food composition of Liza abu (Heckel, 1843) in Tigris River". Basrah J. Agric. Sci., vol. 25, pp. 254-264, 2012.

[21] Mohamed ARM, Hussain NA. "Trophic strains and diet shift of the fish assemblages in the recently restored AlHammar marsh, southern Iraq". Journal of University of Duhok, vol. 15, pp. 115-127, 2012.

[22] Jabir MK, Al-Hisnawi FM. "The food and feeding habits of the greenback grey mullet Liza subviridis (Valenciennes), from Khor Al-Zubair, northwest Arabian Gulf”. Marina Mesopotamica, vol. 9, pp. 357-368, 1994.

[23] Mohamed ARM, Hussein S A, Saleh SA. "The biology of green back grey mullet Liza subviridis in the northwest Arabian Gulf”. Marina Mesopotamica, vol. 13, pp. 375-385, 1998.

[24] Mohamed ARM, Hussain NA, Al-Noor SS, Coad BW, Mutlak FM. "Status of diadromous fish species in the restored East Hammar Marsh in Southern Iraq”. Amer. Fish. Soc., vol. 69, pp. 577-588, 2009.

[25] Al-Dubakel AY. "Analysis of Natural Food Composition of Fishes in Shatt Al-Arab River, Southern Iraq". Jordan Journal of Biological Sciences, vol. 9, pp. 89-96, 2016.

[26] Younis KH, Hussain NA, Yousif UH. "Food and diet overlap of small fish assemblage in the upper reaches of Shatt Al-Arab river. Iraq”. Marina Mesopotamica, vol. 16, pp. 129-139, 2001.

[27] Lazem LF. "Ecological Evaluation of the Shatt Al-Arab River by Applying Geographical Information System (GIS)". Ph.D. Thesis, Basrah University, Basrah, Iraq, 2009.

[28] Taher MM. "Specialization, trophic breadth and diet overlap of thirteen small marine fish species from Shatt AlBasrah Canal, Southern Iraq". Marsh Bulletin, vol. 5, pp. 118-131, 2010.

[29] Nasir NA, Farnar KW. "Feeding ecology of zero group fish community from Shatt al-Arab River in Basrah, Iraq". Journal of Arab Gulf Journal for Scientific Research, vol. 32, pp.1-9, 2014.

[30] Abdullah AJ. "Fish biodiversity and some biological characteristics in the northern part of Shatt Al-Arab River and some of its reaches". Ph.D. Thesis, Basrah University, Basrah, Iraq, 2015.

[31] Mohamed ARM, Hussein SA, Mutlak FM. "The feeding relationships of six fish species in East Hammar marsh, Iraq". Thi-Qar Univ. J. Agric. Res., vol. 4, pp. 460-477, 2015.

[32] Taher MM, Al-Dubakel AY, Al-Lamy JH. "Trophic breadth and dietary overlap for ten fish species caught from Shatt Al-Arab River, Fao, southern Iraq”. Al-Kufa University Journal for Biology, vol. 8, pp.100-109, 2016.

[33] Al-Tawash B, Al-Lafta HS, Merkel B. "Preliminary Assessment of Shatt Al-Arab Riverine Environment, Basra Governorate, Southern Iraq", Journal of Natural Science Research, vol 3, pp. 120-136, 2013. 
[34] Brandimarte L, Popescu I, Neamah NK. "Analysis of fresh-saline water interface at the Shatt Al-Arab estuary", International Journal of River Basin Management, vol 13, pp. 17-25, 2015.

[35] Yaseen BR, Al-Asaady KA, Kazem AA, Chaichan MT. "Environmental Impacts of Salt Tide in Shatt Al-ArabBasra/Iraq", Journal of Environmental Science, Toxicology and Food Technology, vol 10, pp. 35-43, 2016.

[36] Hynes HBN. "The food of fresh water sticklebacks (Gasterosteus aculeatus) and (Pygosteus pungitius) with a review of methods used in studies of food of fishes". Journal of Animal Ecology, vol. 19, pp. 36-58, 1950.

[37] Edmondson WT. "Fresh water biology". John Wiley and Sons Inc. New York, 1248pp, 1959.

[38] Hadi RAM, Al-Saboonchi AA, Haroon AKY. Diatoms of Shatt Al-Arab River, Iraq. Nova Hedwigia, vol. 39, pp. 513-557, 1984.

[39] Wehr JD, Sheath RG. Freshwater algae of North America, ecology classification. San Diego Academic Press, 918 pp, 2003.

[40] Hyslop EJ. "Stomach contents analysis -a review of method and their application". Journal of Fish Biology, vol. 17, pp. 413-422, 1980.

[41] Stergion KI. "Feeding hapites of the lessepsian migrant Siganus luridus in the Eastern Mediternian, its new environment". Journal of Fish Biology, vol. 33pp. 531-543, 1988.

[42] Dipper FA, Bredges CR, Menz, A. "Age, Growth and feeding in the ballon wrasse Labrus bergylta Ascanius 1767". Journal of Fish Biology, vol. 11, pp.105- 120, 1977.

[43] Gordan JD. "The fish population in the store water of west coast Satland. The food and feeding of whiting Merlanguis merlangiu”. Journal of Fish Biology, vol. 11, pp. 512-5291977.

[45] Sarkar UK, Deepak PK. "The diet of clown knife fish Chitala chitala (Hamilton-Buchanan) an endangered notopterid from different wild population (India)". Electronic Journal of Ichthyology, vol .1, pp. 11-20, 2009.

[46] Maia A, Queiroz J, Correia P, Correia H. "Food habits of the short fin mako, Isurusoxyrinchus, off the southwest coast of Portugal". Environmental Biology of Fishes, vol. 77, pp. 157-167, 2006.

[47] Levins R. "Evolution in changing environments". Princeton Uni. Press, New Jersey, USA, 120 p, 1968.

[48] Krebs CJ. "Ecological methodology". Harper Collins, NewYork. 654pp, 1989.

[49] Blackith RE, Reyment RA. “Clustering methods”. In: multivariate morphometris. Academic Press, pp. 290-319, 1971.

[50] Okgerman H, Yardımci CH, Dorak Z, Yilmaz N. "Feeding ecology of vimba (Vimba vimba L., 1758) in terms of size groups and seasons in Lake Sapanca, northwestern Anatolia”. Turkish Journal of Zoology, vol. 37, pp. 287-297, 2013.

[51] Al-Ani SMH, Waha NK. "Food habits of four fish species in Eastern Drainage, Balad, Iraq". Journal of Tikrit University for Agriculture Sciences, vol. 12, pp. 74-84, 2012.

[52] Hussain NA, Saoud HA, Al-Shami EJ. "Specialization, competition and diet overlap of fish assemblages in the recently restored southern Iraqi marshes". Marsh Bulletin, vol. 4, pp. 21-35, 2009.

[53] Abood AN. "Taxonomical study on Mugilid species in Iraqi marine waters and the Garmet Ali River". MSc. Thesis, Basrah University, Basrah, Iraq, 2010.

[54] Coad WB. "Freshwater Fishes of Iraq", Pensoft Publishers, Moscow, 2017.

[55] Sephen JM, Blaber FLS. "The food and feeding ecology of Mugilidae in the St. Lucia lake system". Biological Journal of the Linnean Society, vol. 8, pp. 267-277, 1976.

[56] Fatema K, Wan Maznah Wan Omar WM, Isa M. M. "Identification of Food and Feeding Habits of Mullet Fish, Liza Subviridis (Valenciennes, 1836), Valamugil Buchanani (Bleeker, 1853) from Merbok Estuary, Kedah, Malaysia”. Journal of Life Sciences and Technologies, vol. 1, pp. 47-50, 2013.

[57] Bagenal T. "Methods for the assessment of fish production in fresh waters". 3rd . ed. Blackwell Sci. Publ. Oxford, $365 \mathrm{p}, 1978$.

[58] Johnson JA, Arunachalam M. "Feeding habit and food partitioning in a stream fish community of Western Ghats, India. Environmental Biology of Fishes, vol. 93, pp. 51-60, 2012. 